\title{
Characterization of Chronic Cutaneous Lesions from TNF-Receptor-1-Deficient Mice Infected by Leishmania major
}

\author{
Carolina Ferreira Oliveira, ${ }^{1}$ Daniel Manzoni-de-Almeida, ${ }^{2}$ Paula Seixas Mello, ${ }^{1}$ \\ Caio Cotta Natale, ${ }^{1}$ Helton da Costa Santiago, ${ }^{1}$ Luíza da Silva Miranda, ${ }^{3}$ \\ Fernanda Oliveira Ferraz, ${ }^{2}$ Liliane Martins dos Santos, ${ }^{1}$ Mauro Martins Teixeira, ${ }^{1}$ \\ Rosa Maria Esteves Arantes, ${ }^{3}$ and Leda Quercia Vieira ${ }^{1,2}$
}

\author{
${ }^{1}$ Departamento de Bioquímica e Imunologia, Instituto de Ciências Biológicas, Universidade Federal de Minas Gerais, \\ Avenue Antonio Carlos 6627, 31270-901 Belo Horizonte, MG, Brazil \\ ${ }^{2}$ Núcleo de Pesquisa em Ciências Biológicas, Instituto de Ciências Biológicas e Exatas, Universidade Federal de Ouro Preto, \\ Morro do Cruzeiro, 35400-000 Ouro Preto, MG, Brazil \\ ${ }^{3}$ Departamento de Patologia Geral, Instituto de Ciências Biológicas, Universidade Federal de Minas Gerais, \\ Avenue Antonio Carlos 6627, 31270-901 Belo Horizonte, MG, Brazil
}

Correspondence should be addressed to Leda Quercia Vieira, lqvieira@icb.ufmg.br

Received 15 July 2011; Accepted 28 August 2011

Academic Editor: Alfonso J. Rodriguez-Morales

Copyright (C) 2012 Carolina Ferreira Oliveira et al. This is an open access article distributed under the Creative Commons Attribution License, which permits unrestricted use, distribution, and reproduction in any medium, provided the original work is properly cited.

Leishmania major-infected TNF receptor 1 deficient (TNFR1 KO) mice resolve parasitism but fail to resolve lesions, while wildtype mice completely heal. We investigated the cell composition, cytokine production, and apoptosis in lesions from L. majorinfected TNFR1 KO and wild-type (WT) mice. Chronic lesions from L. major-infected TNFR1 KO mice presented larger number of CD8+ T and Ly6G+ cells. In addition, higher concentrations of mRNA for IFN- $\gamma$ CCL2 and CCL5, as well as protein, but lower numbers of apoptotic cells, were found in lesions from TNFR1 KO mice than in WT, at late time points of infection. Our studies showed that persistent lesions in L. major-infected TNFR1 KO mice may be mediated by continuous migration of cells to the site of inflammation due to the presence of chemokines and also by lower levels of apoptosis. We suggest that this model has some striking similarities to the mucocutaneous clinical form of leishmaniasis.

\section{Introduction}

Parasites of the genus Leishmania cause a spectrum of cutaneous manifestations ranging from limited cutaneous lesions that heal spontaneously to the more severe mucocutaneous form. These different clinical manifestations depend on the species of Leishmania and the host immune response [1, 2]. In experimental models, it is established that BALB/C mice are susceptible to infection by Leishmania major. This mouse strain develops progressive lesions, uncontrolled growth of parasites, visceralization, and death. The C57BL/6 strain is resistant to infection by $L$. major, controls parasite replication, and heals lesions [3]. However, despite clinical and pathological cure of the disease, the parasite remains latent in the host. Resistance to infection by L. major is mediated by IFN- $\gamma$, TNF- $\alpha$, and activation of macrophages to produce nitric oxide [4-6].

Mucocutanesous leishmaniasis is caused mainly by $L$. braziliensis. It is characterized by control of parasite growth in the tissue, but persistent chronic inflammation that commonly affects mucosal tissue causing severe disfiguration and social stigma to the patient [7]. High concentrations of inflammatory cytokines, namely, IFN- $\gamma$ and TNF- $\alpha$, are found in these patients [8]. The study of mucocutaneous leishmaniasis is hampered by lack of a good experimental model. Experimental infection with L. braziliensis causes a very mild and self-limited lesion in C57BL/6 and BALB/C strain mice $[9,10]$. In addition, $L$. amazonensis causes a persistent chronic lesion in C57BL/10 and C57BL/6 mice that lasts over 20 weeks, but both animal models fail to control 
the parasite in the tissue, a hallmark of mucocutaneous leishmaniasis. Moreover, IFN- $\gamma$ and TNF production is impaired in these infection models [11-13]. The closest animal model for mucocutaneous disease would be the infection of C57BL/6 TNFR1-deficient (TNFR1 KO) mice with $L$. major. TNFR1 KO mice control tissue parasitism similarly to the wild-type resistant mouse, but develop nonhealing lesions. However, these lesions do not increase in size progressively. On the contrary, they remain chronic and small, but last for at least 20 weeks afterinfection $[14,15]$.

In experimental infection by L. major, TNF- $\alpha$ is important for activation of macrophages, in cooperation with IFN$\gamma$, and elimination of intracellular parasites $[4,5,16-18]$. Another important fact is the involvement of TNF in the induction of apoptosis in lymphocytes from lesions from wild-type L. major-infected mice [19]. This information may suggest that TNF- $\alpha$ may play a key role in the healing of L. major lesions. However, this important phenomenon was not described in the chronic stage of infection to explain the persistent lesions in L. major-infected TNFR1 KO. Thus, the aim of this study was to characterize events in the chronic phase of L. major infection in TNFR1 KO mice.

\section{Materials and Methods}

2.1. Animals. C57BL/6 wild-type (WT) mice, 6 to 10 weeks old, were obtained from CEBIO (Universidade Federal de Minas Gerais, Belo Horizonte, MG, Brazil). TNFR1 KO mice were originally obtained from the University of Pennsylvania (Philadelphia, Pa, USA, a kind gift from Dr. Phillp Scott and Dr. Klaus Pfeffer) and maintained in Laboratory of the Gnotobiology and Immunology of the Instituto de Ciências Biológicas (UFMG, Brazil). All the procedures involving animals were in accordance with the ethical principles in animal research adopted by the Brazilian College of Animal Experimentation and were approved by the UFMG animal experimentation ethical committee at UFMG (CETEA), protocol number 55/2009.

2.2. Parasites and Infection. A clone of Leishmania major (WHO MHOM/IL/80/Friedlin) was used in this study. Parasites were maintained in Grace's insect medium (GIBCO BRL Life Technologies, Grand Island, NY, USA), pH 6.2, supplemented with $20 \%$ fetal bovine serum (Nutricell, Campinas, SP, Brazil), 2 mM L-glutamine (SIGMA Chemical Co., St. Louis, Mo, USA), $100 \mathrm{U} / \mathrm{mL}$ penicillin and $100 \mu \mathrm{g} / \mathrm{mL}$ streptomycin (GIBCO BRL Life Technologies). Mice were injected in the hind footpads with $1 \times 10^{6} \mathrm{~L}$. major metacyclic promastigotes. Footpads were measured weekly with a caliper (Mitutoyou, Suzano, SP, Brazil). Lesion sizes are expressed as the difference between infected and uninfected footpads.

2.3. Parasite Load. Parasite load in infected footpads was determined by limiting dilution [14]. Results were expressed as the negative log of the last positive dilution.

2.4. Histological Analyzes. Infected footpads from WT and TNFR1 KO mice were removed at 6 and 15 weeks after infection and fixed in $10 \%$ of formalin. Tissues were processed and embedded in paraffin and $5 \mu \mathrm{m}$ thick sections were stained with hematoxylin and eosin and analyzed by light microscopy. At least 10 microscopic fields measuring 250,000 micrometers, representative of lesions, were automatically analysed by KS 300 (Carl Zeiss, Germany) for determining the comparative cellularity of lesions at 15 wks.

2.5. Apoptosis Analysis. Infected footpads from WT and TNFR1 KO mice were removed at 6 and 11 weeks after infection and fixed in 4\% formaldehyde. Apoptotic cells were assessed in situ by the TUNEL reaction, an in situ cell death detection kit (POD, Roche Applied Science, Penzberg, Germany). The results were obtained by counting the number of stained cells per 100 cells (600 cells counted per animal) in 6-10 random areas per histological section.

2.6. Flow Cytometry. Infected footpads from WT and TNFR1 $\mathrm{KO}$ mice were removed at 6 and 15 weeks after infection. Collected tissues were incubated for 90 minutes with $1.5 \mathrm{mg} / \mathrm{mL}$ of collagenase (Sigma-Aldrich, Mo, USA) in RPMI 1640 without supplements at $37^{\circ} \mathrm{C}$, homogenized using a tissue grinder and centrifuged at $2000 \mathrm{~g}$. Singlecell suspensions were stained with fluorochrome-conjugated antibodies (eBioscience, San Diego, Calif, USA) against CD4 (RM4-5), CD8 $\alpha$ (53-6.7), CD3 (17A2), F4/80 (BM8), and Ly6G (RB6-8C5) in PBS containing 1\% FBS for $20 \mathrm{~min}$ on ice and then washed and fixed with $2 \%$ formaldehyde. Stained cells were analyzed using an FACScan flow cytometer equipped with cellQuest software (Becton Dickinson, Heidelberg, Germany). Statistical analyses of mean fluorescence intensity (MFI) were performed using the FlowJo v7.6.5 software (Tree Star Inc., Ashland, Ore, USA).

2.7. Chemokines and Cytokines Analysis. Chemokines and cytokines were analyzed by two methods: detection of mRNA by reverse transcription polymerase chain reaction (RTPCR) and ELISA, at different times of infection (1 and 2 days, 2, 6, and 11 weeks). The footpad was excised and total protein and RNA were extracted with Trizol (GIBCO BRL Laboratories), as previously described. Cytokine and chemokine detections by RT-PCR were performed as previously described [20]. Briefly, L. major-infected and noninfected footpads were harvested and placed in $0.5 \mathrm{~mL}$ TRIZOL (GIBCO BRL) solution and homogenized, and RNA extraction was performed according to the manufacture's instruction. RNA was quantitated spectrophotometricaly and $1 \mu \mathrm{g}$ of RNA was reverse transcribed using $25 \mathrm{U}$ of MMLV Reverse Transcriptase (Promega Corp., Madison, Wis, USA) in $12.5 \mu \mathrm{L}$ reaction containing $2.5 \mathrm{mM}$ dNTPs, $50 \mathrm{mM}$ TRIS/HCl (pH8.3), $75 \mathrm{mM} \mathrm{KCl,} 2 \mathrm{mM} \mathrm{MgCl}_{2}, 10 \mathrm{mM}$ DTT (GIBCO BRL Laboratories, Grand Island, NY, USA), $250 \mathrm{mM}$ dNTP (Promega), $50 \mathrm{mM}$ Tris-HCl, pH 8.3, $75 \mathrm{mM}$ $\mathrm{KCl}, 3 \mathrm{mM} \mathrm{MgCl}_{2}, 10 \mathrm{mM}$ DTT, $10 \mathrm{U}$ RNAsin (GIBCO BRL), and $7.5 \mathrm{pM}$ of oligo $\mathrm{dT}_{15}$ (GIBCO BRL). The mixtures were incubated for $5 \mathrm{~min}$ at $95^{\circ} \mathrm{C}, 5 \mathrm{~min}$ at $4^{\circ} \mathrm{C}$, and $5 \mathrm{~min}$ at $25^{\circ} \mathrm{C}$; at this step $25 \mathrm{U}$ of reverse transcriptase was added to each sample and the reaction mixture was incubated 
TABLE 1: Primers, temperature, and number of cycles used for RT-PCR.

\begin{tabular}{|c|c|c|}
\hline Primer & Sequence & Length (bp) \\
\hline \multirow{3}{*}{ HPRT } & $58^{\circ} \mathrm{C} 32$ cycles & 217 \\
\hline & FW GTT GGA TAC AGG CCA GAC TTT GTT & $546-569$ \\
\hline & RV GAT TCA ACT TGC GCT CAT CTT AGG C & $763-739$ \\
\hline \multirow{3}{*}{ IL-4 } & $60^{\circ} \mathrm{C} 33$ cycles & 292 \\
\hline & FW TTT GAA CGA GGT CAC AGG AG & $195-214$ \\
\hline & RV TGC TCT TTA GGC TTT CCA GG & $487-468$ \\
\hline \multirow{3}{*}{ IFN- $\gamma$} & $60^{\circ} \mathrm{C} 32$ cycles & 202 \\
\hline & FW GGT GAC ATG AAA ATC CTG CAG & $290-310$ \\
\hline & RV GCG CTG GAC CTG TGG GTT GTT GAC C & $493-469$ \\
\hline \multirow{3}{*}{ TNF- $\alpha$} & $62^{\circ} \mathrm{C} 30$ cycles & 300 \\
\hline & FW CGC TCT TCT GTC TAC TGA AC & $293-312$ \\
\hline & RV TGT CCC TTG AAG AGA ACC TG & $593-574$ \\
\hline \multirow{3}{*}{ CCL2 } & $62^{\circ} \mathrm{C} 30$ cycles & 488 \\
\hline & FW CCG GAA TTC CAC TCA CCT GCT GCT ACT CAT TCA & $179-205$ \\
\hline & RV CCG GAA TTC GGA TTC ACA GAG AGG GAA AAA TGG & $667-644$ \\
\hline \multirow{3}{*}{ CCL5 } & $54^{\circ} \mathrm{C} 26$ cycles & 309 \\
\hline & FW CGC GGA TCC CCA CGT CAA GG A GTA TTT CTA CAC C & $184-209$ \\
\hline & RV CGC GAA TCC CTG GTT TCT TGG GTT TGC TGT TG & $493-473$ \\
\hline \multirow{3}{*}{ CCL12 } & $54^{\circ} \mathrm{C} 29$ cycles & 380 \\
\hline & FW GTT CCT GAC TCC TCT AGC TTT C & $11-32$ \\
\hline & RV ACG TAA GAG TTT TTG GAA CTC & $391-371$ \\
\hline \multirow{3}{*}{ CXCL9 } & $54^{\circ} \mathrm{C} 30$ cycles & 398 \\
\hline & FW GAT CAA ACC TGC CTA GAT CC & $302-321$ \\
\hline & RV GGC TGT GTA GAA CAC AGA GT & $700-681$ \\
\hline \multirow{3}{*}{ CXCL10 } & $62^{\circ} \mathrm{C} 27$ cycles & 383 \\
\hline & FW CGC GGA TCC TGA GCA GAG ATG TCT GAA TC & $250-271$ \\
\hline & RV CGC GGA TCC TCG CAC CTC CAC ATA GCT TAC AG & $633-611$ \\
\hline \multirow{3}{*}{ CXCL1 } & $62^{\circ} \mathrm{C} 34$ cycles & 521 \\
\hline & FW CGC GGA T:CC TGG ACC CTG AAG CTC CCT TGG TTC & $226-251$ \\
\hline & RV CGC GGA TCC: CGT GCG TGT TGA CCA TAC ATT ATG & $731-708$ \\
\hline
\end{tabular}

for $60 \mathrm{~min}$ at $37^{\circ} \mathrm{C}$. The temperature was then elevated to $95^{\circ} \mathrm{C}$ for $5 \mathrm{~min}$ and cooled again at $4^{\circ} \mathrm{C}$ for $5 \mathrm{~min}$. The PCR was performed in $10 \mu \mathrm{L}$ reaction of samples diluted in the following buffer: $250 \mathrm{mM}$ dNTP, $10 \mathrm{mM}$ Tris- $\mathrm{HCl} \mathrm{pH}$ 8.3, $50 \mathrm{mM} \mathrm{KCL}, 1.5 \mathrm{mM} \mathrm{MgCl}_{2}, 5 \mathrm{mM}$ of each primer and $0.05 \mathrm{U}$ of TaqPolimerase (Phoneutria, Belo Horizonte, MG, Brazil). For each pair of primers, at least three different numbers of cycles were tested and the best nonsaturating condition was chosen. The PCR was standardized using the house-keeping gene HPRT. The primer sequences (sense and antisense sequence), PCR product size, number of cycles, and temperature of annealing used for each primer are listed in Table 1. The products were electrophoresed in $6 \%$ polyacrilamide gels and developed by silver staining. Primers and PCR conditions are listed in Table 1. For ELISA, footpads were homogenized in PBS $(0.4 \mathrm{M} \mathrm{NaCl}$ and $10 \mathrm{mM}$ de $\left.\mathrm{Na}_{2} \mathrm{HPO}_{4}, \mathrm{pH} 7.2\right)$ containing antiproteases $(0.1 \mathrm{mM}$ phenylmehtylsulfonyl fluoride, $0.1 \mathrm{mM}$ benzethoinium chloride, $10 \mathrm{mM}$ EDTA, and $20 \mathrm{mM} \mathrm{KI}$ aprotin $\mathrm{A} / 100 \mathrm{~mL}$ ) and $0.05 \%$ tween-20. Homogenized tissues were kept on ice for $30 \mathrm{~min}$ and subsequently centrifuged $(3000 \times \mathrm{g}$ for $10 \mathrm{~min})$.
The preparations were assayed using RD Systems kits (Duoset-RD Systems, Minneapolis, Minn, USA) according to instructions. The sensitivity for CCL-2 and CCL-5 was 16 and $32 \mathrm{pg} / \mathrm{mL}$, respectively.

\section{Results}

In this work, we characterized the lesions in L. major-infected TNFR1 KO mice and attempted to explain the reason why these lesions fail to heal. As shown previously [14] $L$. major-infected TNFR1 KO mice develop chronic nonhealing lesions, while WT mice heal lesions over time (Figure 1(a)). In addition, as previously described [14], parasite growth is controlled at the site of infection (Figure 1(b)). WT mice had completely healed lesions at 15 weeks of infection; however, TNFR1 KO mice had conspicuous lesions that led to some loss of function (Figure 1(c)). When histological examination of lesions was performed, we found that, albeit at 6 weeks of infection the inflammatory infiltrate was similar in both groups, at 15 weeks very few inflammatory cells were observed in WT mice, while lesions from TNFR1 KO 


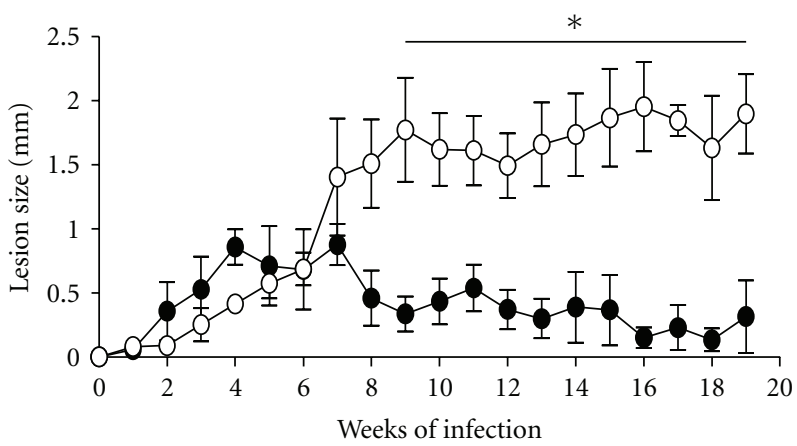

C57BL/6

O TNFR1 KO

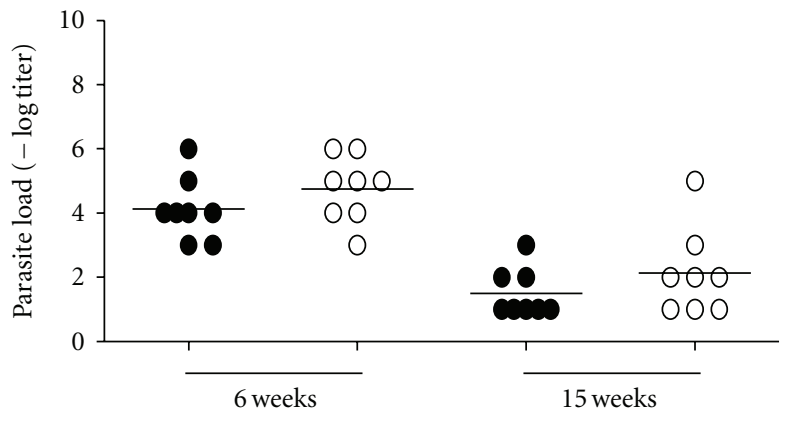

(b)

(a)

TNFR1 KO
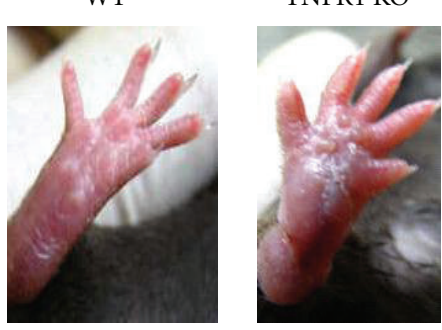

(c)

WT

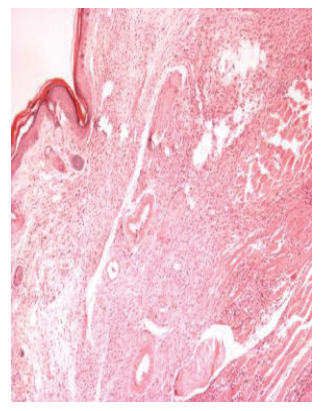

(d)

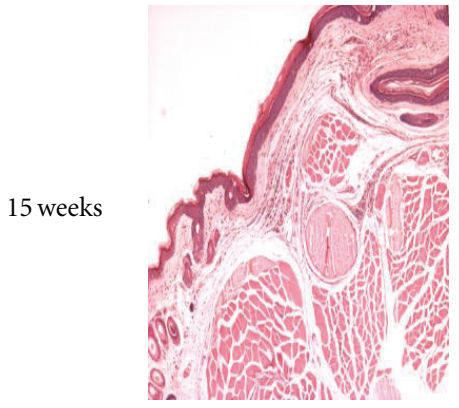

(f)
TNFR1 KO

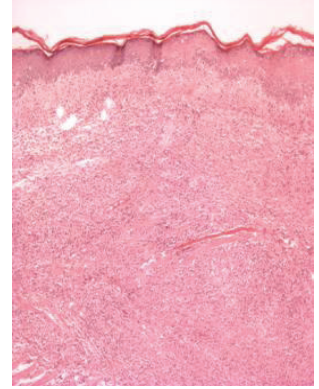

(e)

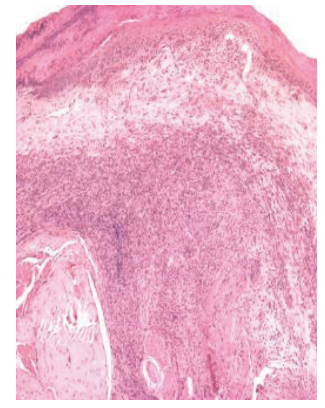

(g)

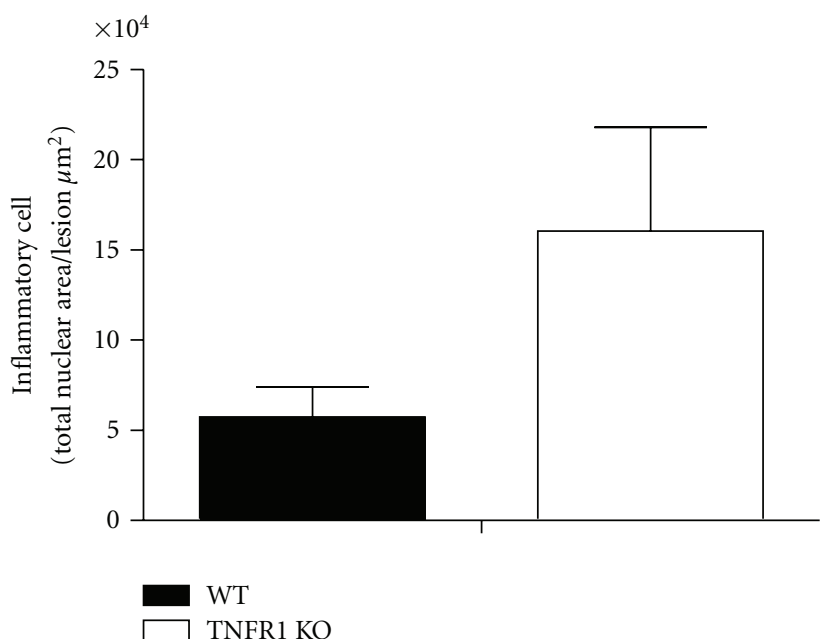

(h)

FIgURE 1: Lesions and parasite burdens in TNFR1 KO mice with L. major. Mice were infected with $1 \times 10^{6}$ metacyclic stationary forms of L. major in footpads. (a) The footpads were measured weekly and the value for uninfected mice was subtracted from each infected footpad to estimate lesion size. (b) Parasite burden in WT and TNFR1 KO mice. Mice were sacrificed at 6 and 15 weeks afterinfection and parasite burden was determined by limiting dilution analysis ( $n=5$ mice per time point). (c) Lesions from WT and TNFR1 KO mice infected with $L$. major 15 weeks afterinfection. (d-g) Histological aspect of tissues from lesions from WT and TNFR1 KO infected for 6 weeks (d and e) or 15 weeks ( $\mathrm{f}$ and $\mathrm{g}$ ), stained with hematoxylin and eosin. (h) Morfometric quantification of inflammatory cells from WT and TNFR1 KO lesions 15 weeks afterinfection $\left(n=4\right.$ mice per group). ${ }^{*}$ indicates $P<0.05$. Data are from one experiment of three performed independently. 
displayed a high number of inflammatory cells (Figures $1(\mathrm{~d})-1(\mathrm{~h}))$.

We further characterized the inflammatory infiltrate by flow cytometry. As seen in Figure 2(a), a higher percentages of CD4+ T lymphocytes was found in lesions from WT mice at 15 weeks of infection. However, since there were more cells in the inflammatory infiltrate in TNFR1 mice, when we calculated the absolute numbers of cells, similar numbers of CD4+ cells were observed in lesions from both groups of mice (Figure 2(b)). Higher percentages and absolute numbers of CD8+ T cells were found in lesions from TNFR1 KO mice (Figures 2(a) and 2(b)). Also, at 15 weeks of infection a higher percentage of macrophages (F4/80 positive cells) was found in WT mice (Figure 2(c)), while a higher percentage of Ly6G positive cells was found in TNFR1 KO mice (Figure 2(c)). In absolute numbers, we found similar numbers of CD4+ T cells and F4/80 cells in both groups of mice (Figure 2(d)) while a higher absolute number of Ly6G+ cells were found in lesions from TNFR1 KO mice (Figure 2(d)). In addition, expression of Ly6G on a per cell basis, indicated by the mean fluorescence intensity (MFI), was increased in these mice (Figure 2(e)).

We proceeded to investigate the expression of cytokines at the site of infection. As seen in Figure 3(a), similar concentrations of mRNA for TNF- $\alpha$ were found in both groups of mice. Similar concentrations of IFN $-\gamma$ mRNA were found in lesions from both groups at 24 and 48 hours of infection, but higher concentrations were found in lesions from TNFR1 KO mice at 11 weeks of infection (Figure 3(b)). In addition, similar concentrations of IL-4 message were found in both groups at all time points tested. These data were confirmed by ELISA at 15 weeks of infection. We found higher TNF- $\alpha$ and IFN- $\gamma$ protein concentrations in L. majorinfected TNFR1KO mice (Figures 3(d) and 3(e)) than in WT mice. No differences were found for IL-4 protein expression between groups of mice (Figures 3(c) and 3(f)).

Since there were more cells at the site of infection in TNFR1 KO mice, we investigated the expression of chemokines by RT-PCR and ELISA. When we assayed CC cytokines, as seen in Figure 4, we found that at 11 weeks of infection there was higher expression of CCL2 and CCL5 mRNA in L. major-infected TNFR1 KO mice than in WT mice (Figures 4(a) and 4(b)). No differences were found in expression of CCL12 mRNA between the groups of mice (Figure 4(c)). We confirmed the results found for CCL2 and CCL 5 by ELISA and found higher concentrations of protein (Figures 4(d) and 4(e)) at 20 weeks of infection in lesions from TNFR1 KO mice. In addition, no differences at later time points were found for CXCL1, CXCL9, and CXCL10 mRNA (data not shown).

In addition to more recruitment, a larger cellular population at the site of infection may be explained by a defective removal of inflammatory cells. Since TNFR1 mediates apoptosis $[19,21]$, we investigated apoptosis at the site of infection at 6 and 11 weeks by the TUNEL reaction. As seen in Figure 5 and quantified in Table 2, at six weeks of infection we saw TUNEL-positive cells in both TNFR1 KO and WT mice. However, at 11 weeks of infection we found higher numbers of TUNEL positive cells in WT mice.

\section{Discussion}

Cutaneous leishmaniasis is characterized by lesions that are self-limited and may heal spontaneously over time. However, approximately $3 \%$ of infected individuals develop the mucocutaneous form of the disease, with chronic ulcerative lesions affecting mucosal tissues and cartilage. One of the features in mucocutaneous leishmaniasis in humans is the prolonged maintenace of lesions [7, 22]. These tissues present an inflammatory infiltrate rich in mononuclear and polymorphonucelar cells [23-26]. High concentrations of IFN- $\gamma$, TNF- $\alpha$, and IL-17 are found in affected tissues and are produced by peripheral blood monocuclear cells from these patients $[8,26,27]$. Another feature is a deficiency in the regulation of the inflammatory processes in mucocutaneous patients, when compared to patients who developed the cutaneous form of the disease [27]. Tissue damage is caused apparently by the inflammatory response, since parasites are detected in low concentrations or not at all in lesions [23$25,28]$. In this work, we studied the chronic cutaneous lesion developed by L. major-infected TNFR1 KO mice. This model presents some of the features found in mucocutaneous patients: control of parasite replication, high concentrations of IFN- $\gamma$ and TNF- $\alpha$, and a large uncontrolled inflammatory infiltrate. Hence, L. major-infected TNFR1 KO mice can control parasite replication, but do not overcome the intense inflammatory process that is observed even after 20 weeks of infection. Thus, lesions in L. major-infected TNFR1 KO mice present some similarities to mucocutaneos lesions in patients infected (Table 2). This model may be useful for studies aimed at interfering with the development of chronic nonhealing lesions caused by Leishmania.

Resolution of $L$. major growth in mice is mediated by nitric oxide produced by nitric oxide synthase 2 (NOS2), which is induced by IFN- $\gamma$ and TNF- $\alpha$ [4-6]. Given the high concentrations of IFN- $\gamma$ and TNF- $\alpha$ present in lesions from TNFR1 KO mice infected with L. major, it is not surprising that these mice control parasite growth. The reason for discrepancy between mRNA and protein expression of TNF$\alpha$ is not known, but we could speculate that there is posttrancriptional regulation or that protein is accumulated at the site of infection, since there is no signaling through TNFR1. Albeit TNF- $\alpha$ was shown to signal through TNFR1 to induce NOS2, alternative pathways in TNFR1 KO mice have been proposed $[15,29,30]$. In fact, mice deficient in both receptors for TNF are capable of controlling parasite burdens [15], and it has been proposed that direct contact with T cells (via CD40L and LFA1) would substitute for TNF$\alpha$ [29]. Thus, as previously described $[14,15]$, we show here that persistence of lesions in TNFR1 KO is not mediated by the persistence of parasites at the site of infection.

TNF- $\alpha$ is the starting factor that mediates cell infiltration to a site of infection or tissue damage [21]. Accordingly, it has been shown that in an HSV-1 encephalites mouse model, TNFR1 mice present a smaller cellular infiltrate in response to tissue damage [31]. In other models, it has been shown that TNFR1 KO mice do not control the inflammatory infiltrate and damage tissue [19, 30, 32-35]. In this work, we characterized the cellular infiltrate in lesions from TNFR1 


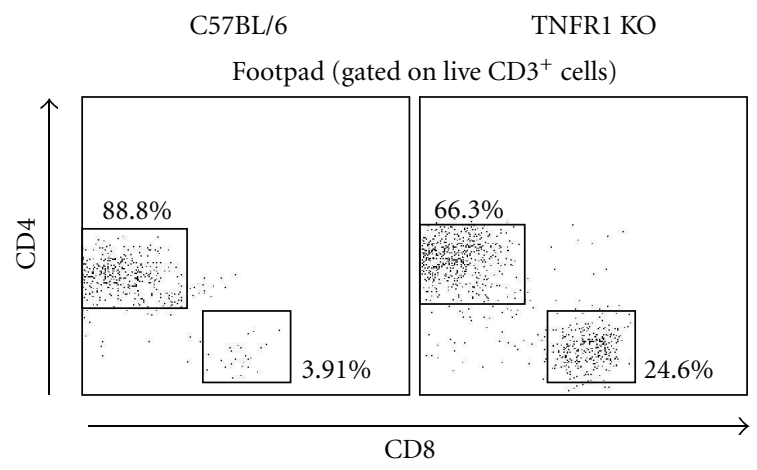

(a)
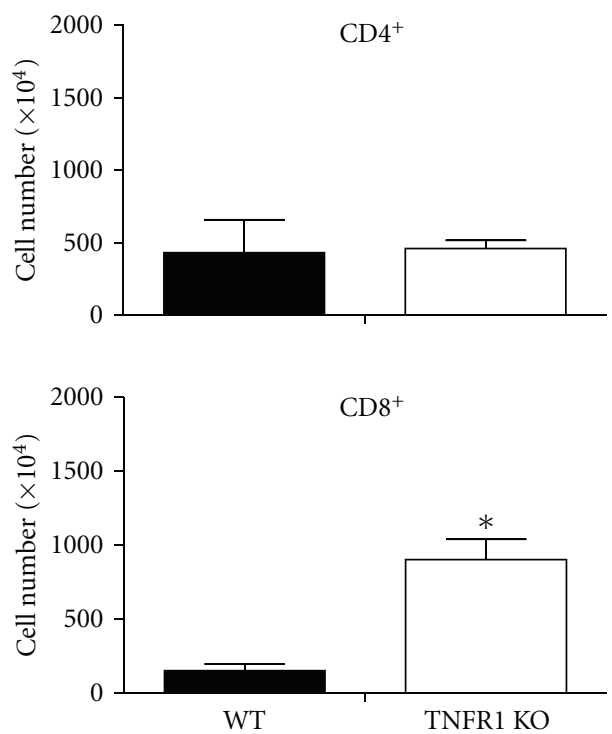

- WT

$\square$ TNFR1 KO

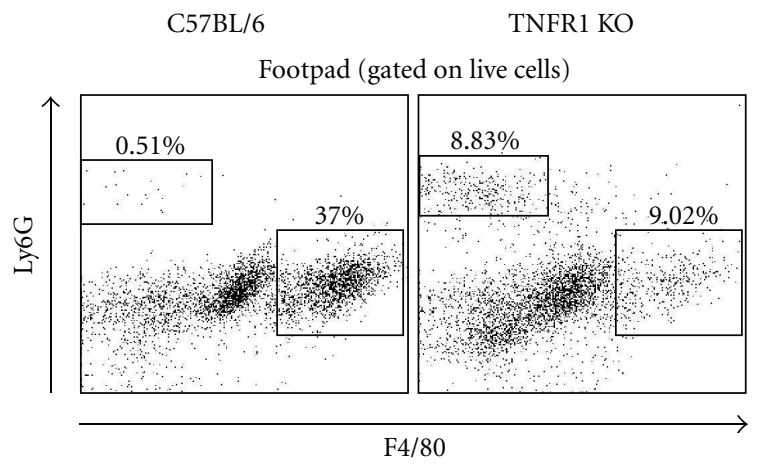

(c)
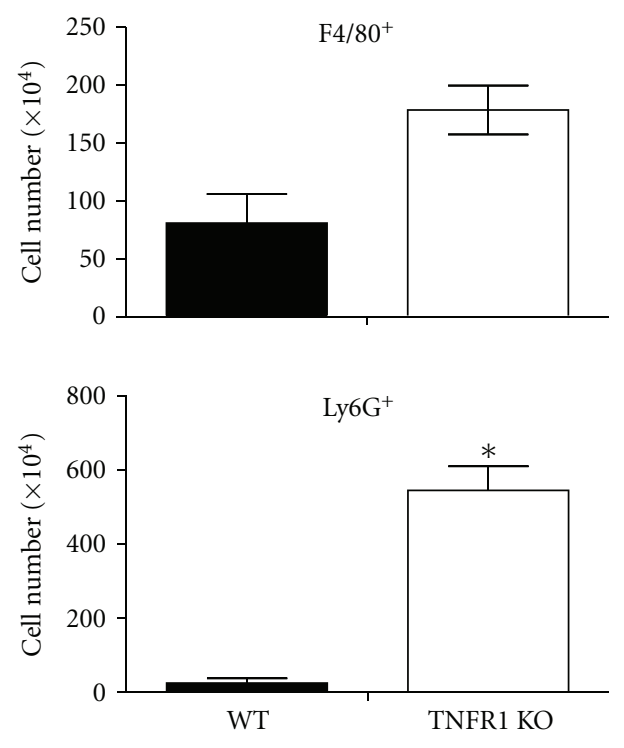

- WT

$\square$ TNFR1 KO

(b)

(d)

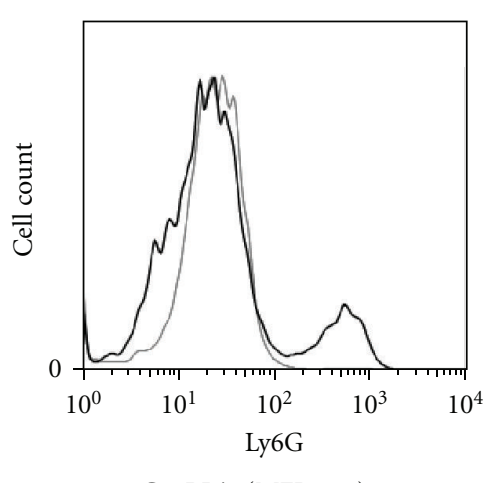

C57BL/6 (MFI 31.2)

— TNFR1-/- (MFI339)

(e)

FIgURE 2: Cell populations in lesions from WT and TNFR1 KO mice infected with L. major. Mice were infected in the footpad with $1 \times 10^{6}$ L. major and 15 weeks post-infection the inflammatory cells were isolated from lesions and characterized by flow cytometry. (a) Dot plots and (b) absolute cell numbers of CD4+ and CD8+ T cells from pooled lesions from 4 mice per group. (c) Dot plots and (d) absolute cell numbers of F4/80+ and Ly6G+ cells from pooled lesions from 4 mice per group. (e) Ly6G fluorescence intensity. ${ }^{*} P<0.05$. Data are from one experiment. 


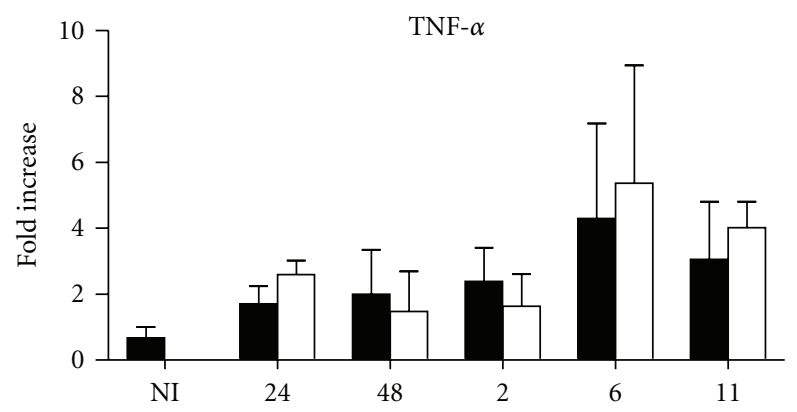

(a)

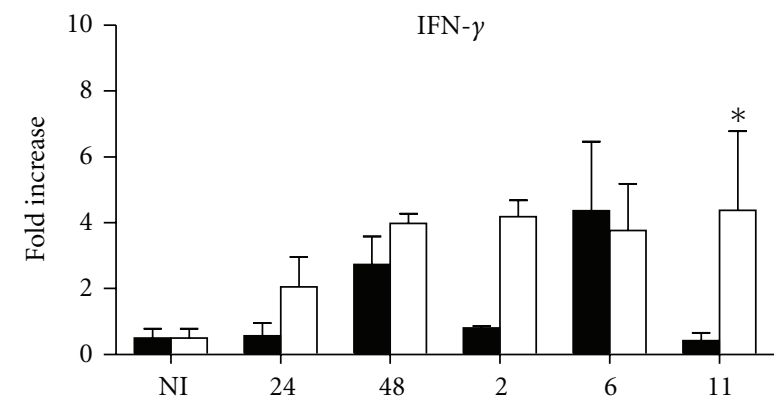

(b)

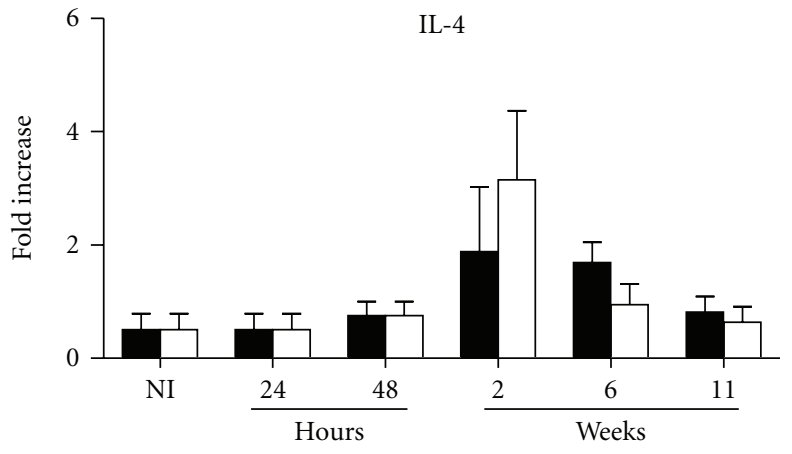

- WT

$\square$ TNFR1 KO

(c)

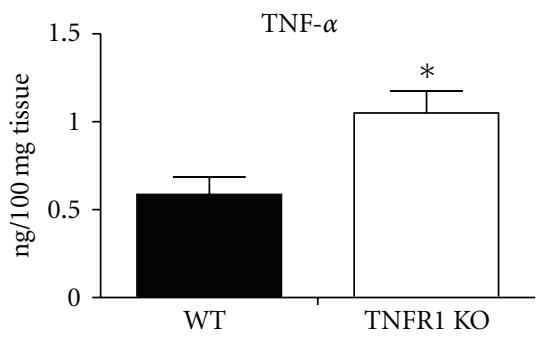

(d)

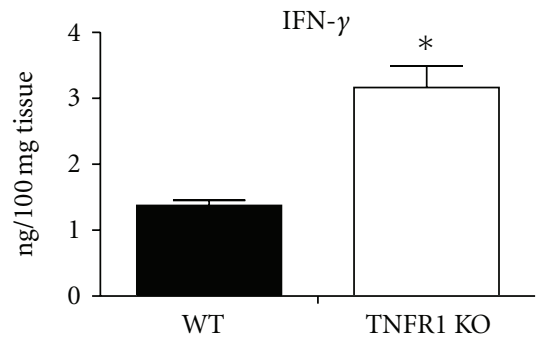

(e)

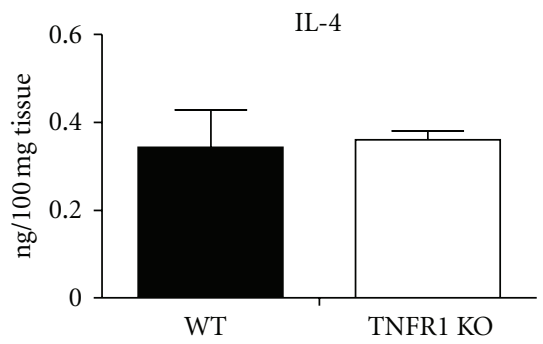

(f)

FIGURE 3: TNF- $\alpha$, IFN- $\gamma$, and IL-4 in lesions from WT and TNFR1 KO mice infected with L. major. Mice were infected in both footpads with L. major $\left(1 \times 10^{6}\right)$. At 24 and $48 \mathrm{~h}$ and at 2,6, and 11 weeks after infection, mice were killed, lesions were harvested, and RT-PCR reactions performed for cytokines. At 15 weeks protein was assayed by ELISA. (a-c) Fold increase in TNF- $\alpha$, IFN- $\gamma$, and IL-4 mRNA, obtained by densitometry of bands in gels, as described in Section 2. (d-f) TNF- $\alpha$, IFN- $\gamma$, and IL-4 protein was determined by ELISA 15 weeks after infection. Data shown are from one experiment representative of two indenpendently performed ones, with four mice per group. ${ }^{*} P<0.05$. 


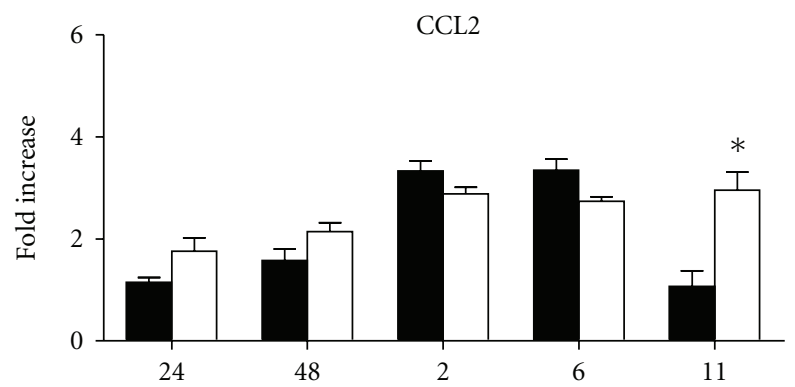

(a)

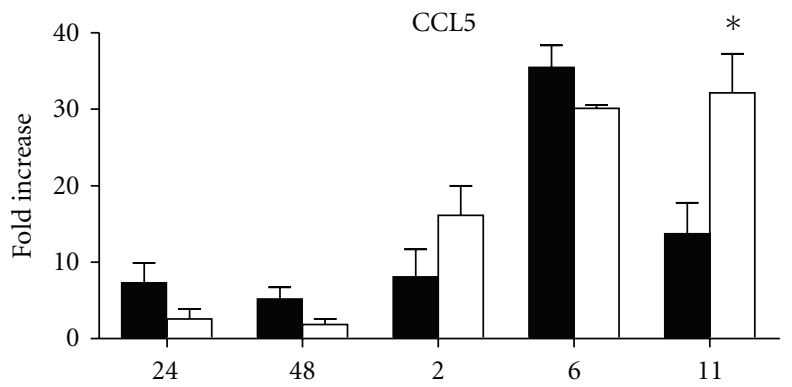

(b)

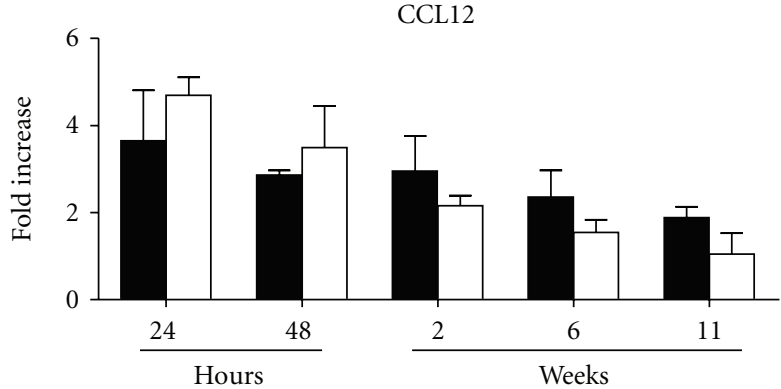

- WT

$\square$ TNFR1 KO

(c)

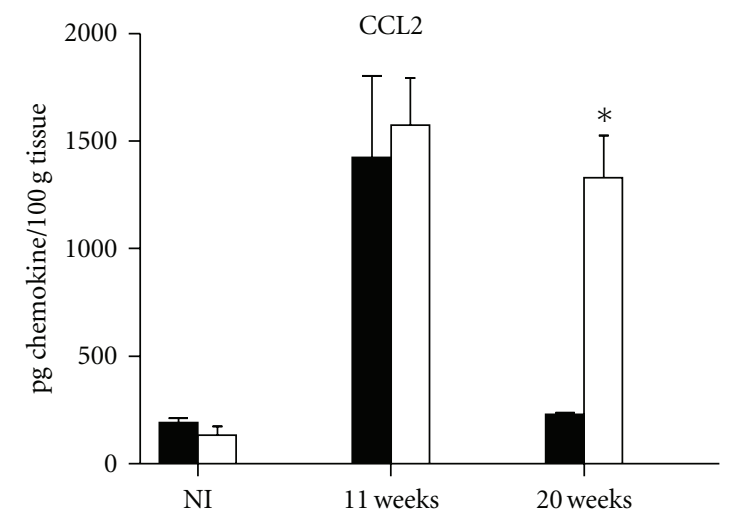

(d)

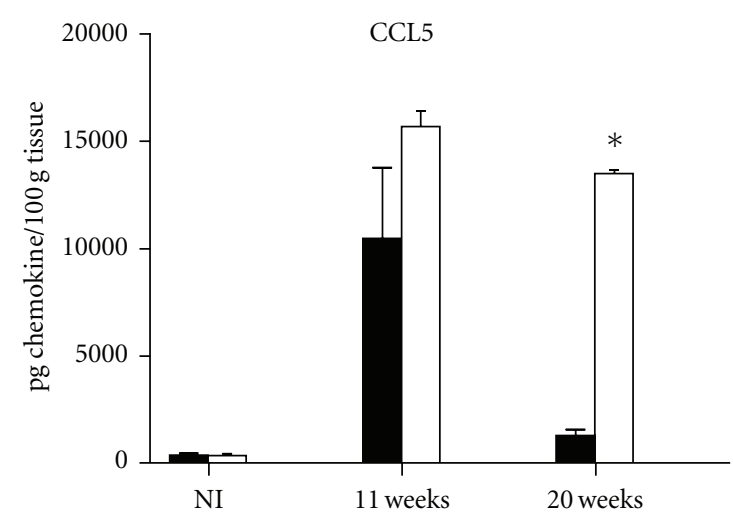

(e)

Figure 4: CCL2, CCL12, and CCL5 in lesions from WT and TNFR1 KO mice infected with L. major. Mice were infected in both footpads with L. major $\left(1 \times 10^{6}\right)$. At 24 and $48 \mathrm{~h}$ and at 2,6, and 11 weeks after infection, mice were killed, lesions were harvested and RT-PCR reactions were performed for chemokines. At 15 weeks, protein was assayed by ELISA. (a-c) Fold increase for CCL2, CCL12, and CCL5 mRNA, obtained by densitometry of bands in gels, as described in Section 2. (d-e) CCL2 and CCL5 determined by ELISA in footpads of naïve mice (NI), and mice infected for 11 and 20 weeks. Data shown are from a single experiment representative of two separate experiments performed with four mice per group. ${ }^{*} P<0.05$. 


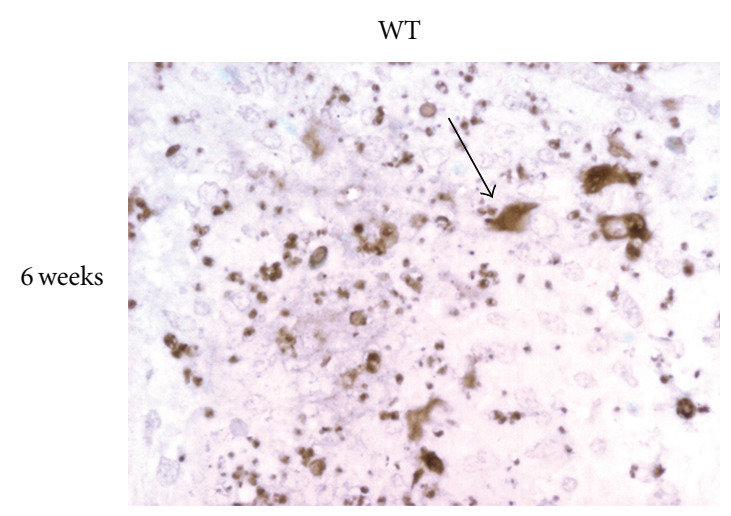

(a)

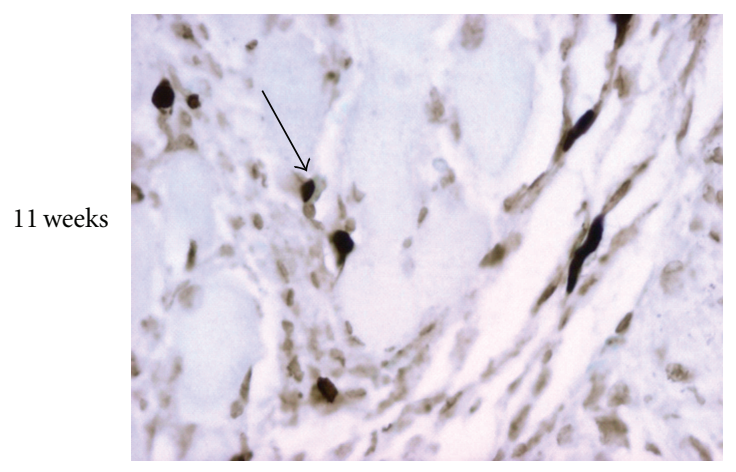

(c)
TNFR1 KO

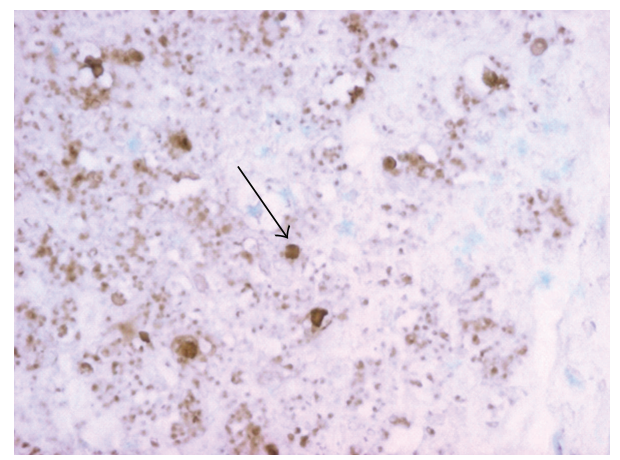

(b)

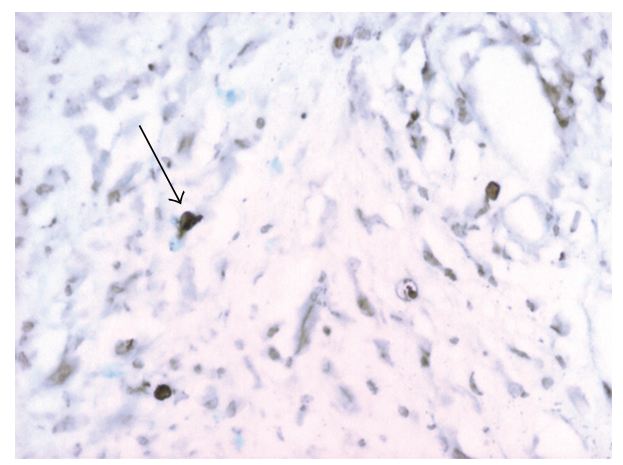

(d)

Figure 5: Apoptosis in lesions from WT and TNFR1 KO mice infected by L. major. Mice were infected with L. major in the footpad (1 $\left.\times 10^{6}\right)$ and after 6 weeks ( $\mathrm{a}$ and $\mathrm{b}$ ) and 11 weeks ( $\mathrm{c}$ and $\mathrm{d}$ ) of infection. Tissues were stained by TUNEL, as described in Section 2. Arrows indicate TUNEL positive cells.

KO mice. We found that, at later times of infection, there were more neutrophils and CD8+ T cells in lesions from TNFR1 KO than in WT mice. CD8+ $\mathrm{T}$ cells have been implicated in the exacerbation of tissue injury in patients suffering from mucocutaneous form of leishmaniasis [3638]. Likewise, the presence of neutrophils has been associated with a high concentration of IL-17 in areas of tissue damage in patients infected with $L$. braziliensis who developed mucocutaneous leishmaniasis $[25,26]$. We also found lower percentages of F4/80-expressing macrophages in lesions from TNFR1 KO mice at 15 weeks afterinfection. This seems to be due to the presence of other cells in the same gate (e.g., neutrophils), since absolute numbers of macrophages were similar in both groups of mice. However, the smaller percentage of macrophages (which is not a smaller absolute number) did not compromise the control of parasites by TNFR1 KO mice.

Cell recruitment to sites of infection or tissue damage is mediated by chemokines [39]. In an attempt to explain the larger cellular infiltrate in TNFR1 KO mice, we determined the concentrations of mRNA for chemokines at several times of infection. At the earlier times of infection the concentrations of the chemokines assessed were similar in both groups. This observation is in accordance with our previous observations that initial cellular recruitment is not affected by the TNFR1, in a model of angiogenesis [40]. However, at 11 weeks of infection, when lesions were significantly different, we found higher expression of CCL5 and CCL 2 mRNA and, at 20 weeks afterinfection, we found higher concentrations of CCL5 and CCL2 protein in lesions. This could be simply due to a larger number of cells at the site of infection; however, this is unlikely, since for CCL12 and other chemokines (not shown) we failed to observe the same effect. CCL5 and CCL2 are implicated on the migration of macrophages, monocytes, NK, and T cells to sites of injury [41-43]. Thus, it may be that the persistence of exacerbated inflammatory cells at the site of infection with L. major in TNFR1 KO is related with high concentrations of these two chemokines that are promoting the recruitment of more cells.

Apoptosis is required for the clearance of inflammatory cells from tissues, once the stimulus for recruitment of pathogens or damage is gone $[44,45]$. TNFR1 mediates apoptosis, since it contains a cell death domain [46, 47]. In fact, it had previously been shown that there was defective apoptosis at the site of infection of Rhodococcus equis. Moreover, cells from R. equis-infected lungs of WT mice and from footpads of L. major-infected WT were sensitive only to TNFmediated apoptosis. However, cells from TNFR1 KO mice infected with either $R$. equis or $L$. major were not sensitive 
TABLE 2: Quantification of apoptosis at the site of infection by L. major in WT and TNFR1 KO mice.

\begin{tabular}{lcccr}
\hline & \multicolumn{2}{c}{ C57BL/6 } & \multicolumn{2}{c}{ TNFR1 KO } \\
& Mean & Standard error & Mean & Standard error \\
\hline 6 weeks & $\mathbf{7 . 0 4}^{\mathrm{b}}$ & 0.72 & $\mathbf{6 . 7 5}$ & 1.00 \\
11 weeks & $\mathbf{8 . 1 5}^{\mathrm{c}}$ & 1.01 & $\mathbf{2 . 9 1}$ & 0.52 \\
\hline
\end{tabular}

${ }^{a}$ Mice were infected with L. major in the footpad $\left(1 \times 10^{6}\right)$ and after 6 and 11 weeks of infection animals were sacrificed and the lesions collected. Tissues were stained by TUNNEL, as described in Section 2. Apoptotic nuclei were counted and results expressed as apoptotic nuclei per 100 nuclei. Results represent the mean of 3-6 animals; six sections were counted per mouse.

${ }^{\mathrm{b}} P=0.37$ Student's $t$-test.

${ }^{\mathrm{c}} P=0.0005$ Student's $t$-test.

TABLE 3: Comparison between human mucocutaneous and TNFR1 KO lesions.

\begin{tabular}{lcc}
\hline Characteristic & $\begin{array}{c}\text { Mucocutaneous } \\
\text { leishmaniasis }\end{array}$ & $\begin{array}{c}\text { L. major-infected } \\
\text { TNFR1 KO }\end{array}$ \\
Chronic cutaneous lesions & Yes & Yes \\
Intense inflammatory cells infiltrate in chronic phase & Yes & Yes \\
Low parasite load in lesions & Yes & Yes \\
High production of proinflammatory cytokines (IFN- $\gamma$ and TNF- $\alpha$ ) in the lesions & Yes & Yes \\
Defect in the regulation of inflammatory response & Yes & Yes \\
Presence of high numbers of CD8+ T cells and neutrophils in lesions & Yes \\
High levels of IL-17 & Yes & Yes \\
Invasion of mucosal tissues & Not determined \\
\hline
\end{tabular}

to TNF- $\alpha$-mediated apoptosis [19]. Thus, we investigated apoptosis, in situ, in lesions from WT and TNFR1 KO mice. At 6 weeks of infection, both mouse strains showed similar concentrations of TUNEL positive cells, thus suggesting that at this time point apoptosis occurred independently of the TNFR1. However, at 11 weeks of infection, when WT mice were healing and TNFR1 KO mice had a large inflammatory infiltrate at the site of infection, lesions from WT mice had significantly more TUNEL positive cells than lesions from TNFR1 KO mice. This indicated to us that TNFR1 plays a crucial role in the clearance of the inflammatory infiltrate and in the healing of lesions.

\section{Conclusion}

In this paper, we implicated persistent chemokine production and defective apoptosis as the factors that prevent healing of lesions in TNFR1 KO mice. In addition, characterization of parasite burden, cellular infiltrate, and cytokine production allowed us to propose the TNFR1 KO infected with L. major as a model to study chronic nonhealing lesions found in patients that present the mucocutaneous clinical form of leishmaniasis (Table 3 ).

\section{Acknowledgments}

The authors are indebted to Mr. Antonio Mesquita Vaz for expert animal care, to Ms. Vânia Aparecida N. Silva for technical assistance, and to FUNDEP for administration of the funds. This work was supported by FAPEMIG Grant nos. EDT-468/07 and CNPq Grant no. 304776/2009-2 and 571093/2008-6. C. F. Oliveira, F. O. Ferraz, and L. M. dos
Santos are CAPES fellows, the remaining authors are $\mathrm{CNPq}$ fellows. C. F. Oliveira and D. M. de-Almeida contributed equally to the present study.

\section{References}

[1] J. Convit, M. Ulrich, C. T. Fernandez et al., "The clinical and immunological spectrum of American cutaneous leishmaniasis," Transactions of the Royal Society of Tropical Medicine and Hygiene, vol. 87, no. 4, pp. 444-448, 1993.

[2] F. T. Silveira, R. Lainson, and C. E. P. Corbett, "Clinical and immunopathological spectrum of American cutaneous leishmaniasis with special reference to the disease in Amazonian Brazil: a review," Memorias do Instituto Oswaldo Cruz, vol. 99, no. 3, pp. 239-251, 2004.

[3] D. Sacks and N. Noben-Trauth, "The immunology of susceptibility and resistance to Leishmania major in mice," Nature Reviews Immunology, vol. 2, no. 11, pp. 845-858, 2002.

[4] F. Y. Liew, Y. Li, and S. Millott, "Tumor necrosis factor$\alpha$ synergizes with IFN- $\gamma$ in mediating killing of Leishmania major through the induction of nitric oxide," Journal of Immunology, vol. 145, no. 12, pp. 4306-4310, 1990.

[5] S. J. Green, R. M. Crawford, J. T. Hockmeyer, M. S. Meltzer, and C. A. Nacy, "Leishmania major amastigotes initiate the L-arginine-dependent killing mechanism in IFN- $\gamma$-stimulated macrophages by induction of tumor necrosis factor- $\alpha 1$," Journal of Immunology, vol. 145, no. 12, pp. 4290-4297, 1990.

[6] F. Q. Cunha, J. Assreuy, S. Moncada, and F. Y. Liew, "Phagocytosis and induction of nitric oxide synthase in murine macrophages," Immunology, vol. 79, no. 3, pp. 408-411, 1993.

[7] M. M. Lessa, H. A. Lessa, T. W. N. Castro et al., "Mucosal leishmaniasis: epidemiological and clinical aspects," The Brazilian Journal of Otorhinolaryngology, vol. 73, no. 6, pp. 843-847, 2007. 
[8] O. Bacellar, H. Lessa, A. Schriefer et al., "Up-regulation of Th1type responses in mucosal leishmaniasis patients," Infection and Immunity, vol. 70, no. 12, pp. 6734-6740, 2002.

[9] J. Samuelson, E. Lerner, R. Tesh, and R. Titus, "A mouse model of Leishmania braziliensis braziliensis infection produced by coinjection with sand fly saliva," Journal of Experimental Medicine, vol. 173, no. 1, pp. 49-54, 1991.

[10] T. R. de Moura, F. O. Novais, F. Oliveira et al., "Toward a novel experimental model of infection to study American cutaneous leishmaniasis caused by Leishmania braziliensis," Infection and Immunity, vol. 73, no. 9, pp. 5827-5834, 2005.

[11] L. C. C. Afonso and P. Scott, "Immune responses associated with susceptibility of C57BL/10 mice to Leishmania amazonensis," Infection and Immunity, vol. 61, no. 7, pp. 2952-2959, 1993.

[12] V. Lemos De Souza, J. A. Souza, T. M. Correia Silva, P. Sampaio Tavares Veras, and L. A. Rodrigues De-Freitas, "Different Leishmania species determine distinct profiles of immune and histopathological responses in CBA mice," Microbes and Infection, vol. 2, no. 15, pp. 1807-1815, 2000.

[13] J. Ji, J. Sun, and L. Soong, "Impaired expression of inflammatory cytokines and chemokines at early stages of infection with Leishmania amazonensis," Infection and Immunity, vol. 71, no. 8, pp. 4278-4288, 2003.

[14] L. Q. Vieira, M. Goldschmidt, M. Nashleanas, K. Pfeffer, T. Mak, and P. Scott, "Mice lacking the TNF receptor p55 fail to resolve lesions caused by infection with Leishmania major, but control parasite replication," Journal of Immunology, vol. 157, no. 2, pp. 827-835, 1996.

[15] M. Nashleanas and P. Scott, "Activated T cells induce macrophages to produce NO and control Leishmania major in the absence of tumor necrosis factor receptor p55," Infection and Immunity, vol. 68, no. 3, pp. 1428-1434, 2000.

[16] C. M. Theodos, L. Povinelli, R. Molina, B. Sherry, and R. G. Titus, "Role of tumor necrosis factor in macrophage leishmanicidal activity in vitro and resistance to cutaneous leishmaniasis in vivo," Infection and Immunity, vol. 59, no. 8, pp. 2839 2842, 1991.

[17] J. P. Sypek and D. J. Wyler, "Antileishmanial defense in macrophages triggered by tumor necrosis factor expressed on CD4+ T lymphocyte plasma membrane," Journal of Experimental Medicine, vol. 174, no. 4, pp. 755-759, 1991.

[18] T. P. Birkland, J. P. Sypek, and D. J. Wyler, "Soluble TNF and membrane TNF expressed on CD4+ T lymphocytes differ in their ability to activate macrophage antileishmanial defense," Journal of Leukocyte Biology, vol. 51, no. 3, pp. 296-299, 1992.

[19] S. T. Kanaly, M. Nashleanas, B. Hondowicz, and P. Scott, "TNF receptor p55 is required for elimination of inflammatory cells following control of intracellular pathogens," Journal of Immunology, vol. 163, no. 7, pp. 3883-3889, 1999.

[20] H. C. Santiago, M. F. Braga Pires, D. G. Souza et al., "Platelet activating factor receptor-deficient mice present delayed interferon-gamma upregulation and high susceptibility to Leishmania amazonensis infection," Microbes and Infection, vol. 8, no. 11, pp. 2569-2577, 2006.

[21] N. P. Malek, J. Pluempe, S. Kubicka, M. P. Manns, and C. Trautwein, "Molecular mechanisms of TNF receptormediated signaling," Recent Results in Cancer, vol. 147, pp. 97106, 1998.

[22] V. S. Amato, H. F. De Andrade, and M. I. S. Seixas Duarte, "Mucosal leishmaniasis: in situ characterization of the host inflammatory response, before and after treatment," Acta Tropica, vol. 85, no. 1, pp. 39-49, 2003.
[23] D. S. Ridley, A. V. De Magalhaes, and P. D. Marsden, "Histological analysis and the pathogenesis of mucocutaneous leishmaniasis," Journal of Pathology, vol. 159, no. 4, pp. 293-299, 1989.

[24] D. S. Ridley, P. D. Marsden, C. C. Cuba, and A. C. Barreto, "A histological classification of mucocutaneous leishmaniasis in Brazil and its clinical evaluation," Transactions of the Royal Society of Tropical Medicine and Hygiene, vol. 74, no. 4, pp. 508-514, 1980.

[25] B. Azadeh, A. Samad, and S. Ardehali, "Histological spectrum of cutaneous leishmaniasis due to Leishmania tropica," Transactions of the Royal Society of Tropical Medicine and Hygiene, vol. 79, no. 5, pp. 631-636, 1985.

[26] V. S. Boaventura, C. S. Santos, C. R. Cardoso et al., "Human mucosal leishmaniasis: neutrophils infiltrate areas of tissue damage that express high levels of Th17-related cytokines," European Journal of Immunology, vol. 40, no. 10, pp. 28302836, 2010.

[27] D. R. Faria, K. J. Gollob, J. Barbosa et al., "Decreased in situ expression of interleukin-10 receptor is correlated with the exacerbated inflammatory and cytotoxic responses observed in mucosal leishmaniasis," Infection and Immunity, vol. 73, no. 12, pp. 7853-7859, 2005.

[28] M. N. Sotto, E. H. Yamashiro-Kanashiro, V. L. R. Da Matta, and T. De Brito, "Cutaneous leishmaniasis of the New World: diagnostic immunopathology and antigen pathways in skin and mucosa," Acta Tropica, vol. 46, no. 2, pp. 121-130, 1989.

[29] M. Nashleanas, S. Kanaly, and P. Scott, "Control of Leishmania major infection in mice lacking TNF receptors," Journal of Immunology, vol. 160, no. 11, pp. 5506-5513, 1998.

[30] G. S. Yap, T. Scharton-Kersten, H. Charest, and A. Sher, "Decreased resistance of TNF receptor p55- and p75-deficient mice to chronic toxoplasmosis despite normal activation of inducible nitric oxide synthase in vivo," Journal of Immunology, vol. 160, no. 3, pp. 1340-1345, 1998.

[31] M. C. Vilela, G. K. Lima, D. H. Rodrigues et al., "TNFR1 plays a critical role in the control of severe HSV-1 encephalitis," Neuroscience Letters, vol. 479, no. 1, pp. 58-62, 2010.

[32] J. L. Flynn, M. M. Goldstein, J. Chan et al., "Tumor necrosis factor- $\alpha$ is required in the protective immune response against mycobacterium tuberculosis in mice," Immunity, vol. 2, no. 6, pp. 561-572, 1995.

[33] N. S. Gonçalves, M. Ghaem-Maghami, G. Monteleone et al., "Critical role for tumor necrosis factor alpha in controlling the number of lumenal pathogenic bacteria and immunopathology in infectious colitis," Infection and Immunity, vol. 69, no. 11, pp. 6651-6659, 2001.

[34] M. S. Di Genaro, D. E. Cargnelutti, J. R. Eliçabe et al., "Role of TNFRp55 in Yersinia enterocolitica O:3-induced arthritis: triggering bacterial antigens and articular immune response," Rheumatology, vol. 46, no. 4, pp. 590-596, 2007.

[35] R. J. Eliçabe, E. Cargnelutti, M. I. Serer et al., "Lack of TNFR p55 results in heightened expression of ifn- $\gamma$ and IL-17 during the development of reactive arthritis," Journal of Immunology, vol. 185, no. 7, pp. 4485-4495, 2010.

[36] M. Barral-Netto, A. Barral, C. Brodskyn, E. M. Carvalho, and S. G. Reed, "Cytotoxicity in human mucosal and cutaneous leishmaniasis," Parasite Immunology, vol. 17, no. 1, pp. 21-28, 1995.

[37] C. I. Brodskyn, A. Barral, V. Boaventura, E. Carvalho, and M. Barral-Netto, "Parasite-driven in vitro human lymphocyte cytotoxicity against autologous infected macrophages from mucosal leishmaniasis," Journal of Immunology, vol. 159, no. 9, pp. 4467-4473, 1997. 
[38] J. H. Ruiz and I. Becker, "CD8 cytotoxic T cells in cutaneous leishmaniasis," Parasite Immunology, vol. 29, no. 12, pp. 671678, 2007.

[39] A. Rot and U. H. Von Andrian, "Chemokines in innate and adaptive host defense: basic chemokinese grammar for immune cells," Annual Review of Immunology, vol. 22, pp. 891-928, 2004.

[40] L. S. Barcelos, A. Talvani, A. S. Teixeira et al., "Impaired inflammatory angiogenesis, but not leukocyte influx, in mice lacking TNFR1," Journal of Leukocyte Biology, vol. 78, no. 2, pp. 352-358, 2005.

[41] P. Allavena, G. Bianchi, D. Zhou et al., "Induction of natural killer cell migration by monocyte chemotactic protein-1, -2 and -3," European Journal of Immunology, vol. 24, no. 12, pp. 3233-3236, 1994.

[42] U. Ritter and H. Moll, "Monocyte chemotactic protein1 stimulates the killing of Leishmania major by human monocytes, acts synergistically with IFN- $\gamma$ and is antagonized by IL-4," European Journal of Immunology, vol. 30, no. 11, pp. 3111-3120, 2000.

[43] S. Oghumu, C. M. Lezama-Dávila, A. P. Isaac-Márquez, and A. R. Satoskar, "Role of chemokines in regulation of immunity against leishmaniasis," Experimental Parasitology, vol. 126, no. 3, pp. 389-396, 2010.

[44] J. Savill, I. Dransfield, C. Gregory, and C. Haslett, "A blast from the past: clearance of apoptotic cells regulates immune responses," Nature Reviews Immunology, vol. 2, no. 12, pp. 965-975, 2002.

[45] D. El Kebir and J. G. Filep, "Role of neutrophil apoptosis in the resolution of inflammation," TheScientificWorldJournal, vol. 10, pp. 1731-1748, 2010.

[46] N. Parameswaran and S. Patial, "Tumor necrosis factor-alpha signaling in macrophages," Critical Reviews in Eukaryotic Gene Expression, vol. 20, no. 2, pp. 87-103, 2010.

[47] P. J. Naude, J. A. den Boer, P. G. M. Luiten, and U. L. M. Eisel, "Tumor necrosis factor receptor cross-talk," The FEBS Journal, vol. 278, no. 6, pp. 888-898, 2011. 


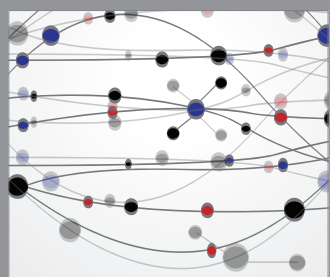

The Scientific World Journal
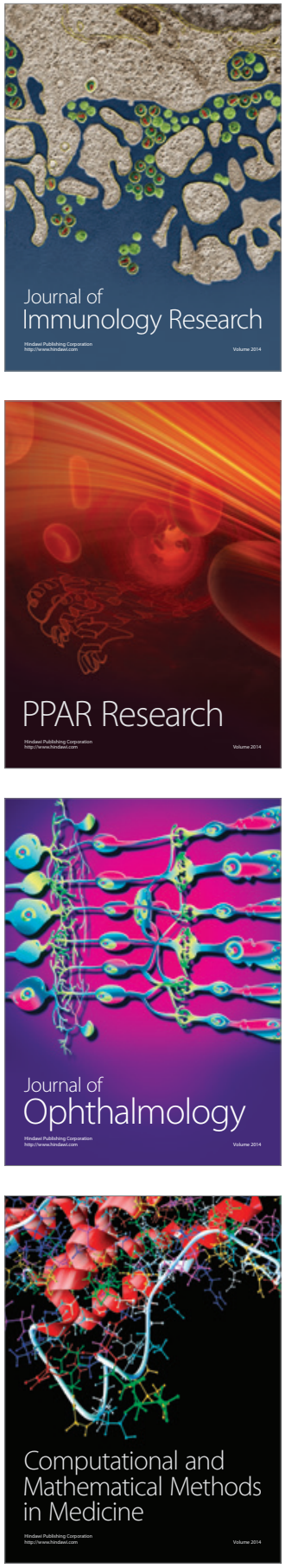

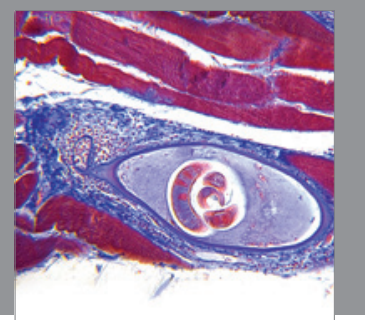

Gastroenterology

Research and Practice
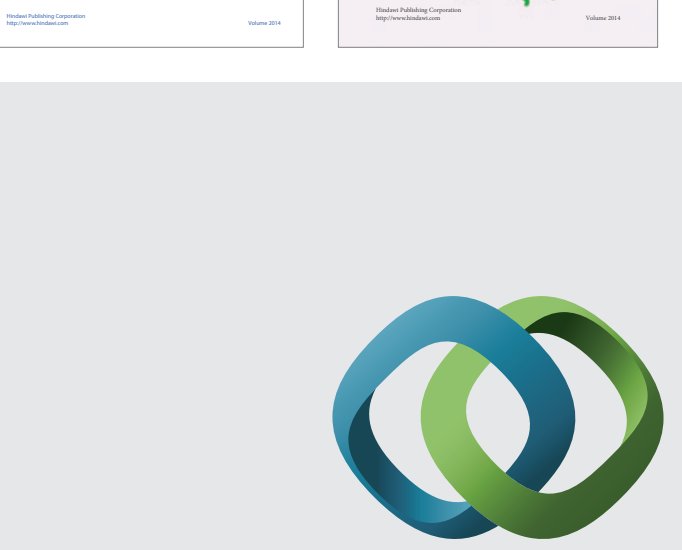

\section{Hindawi}

Submit your manuscripts at

http://www.hindawi.com
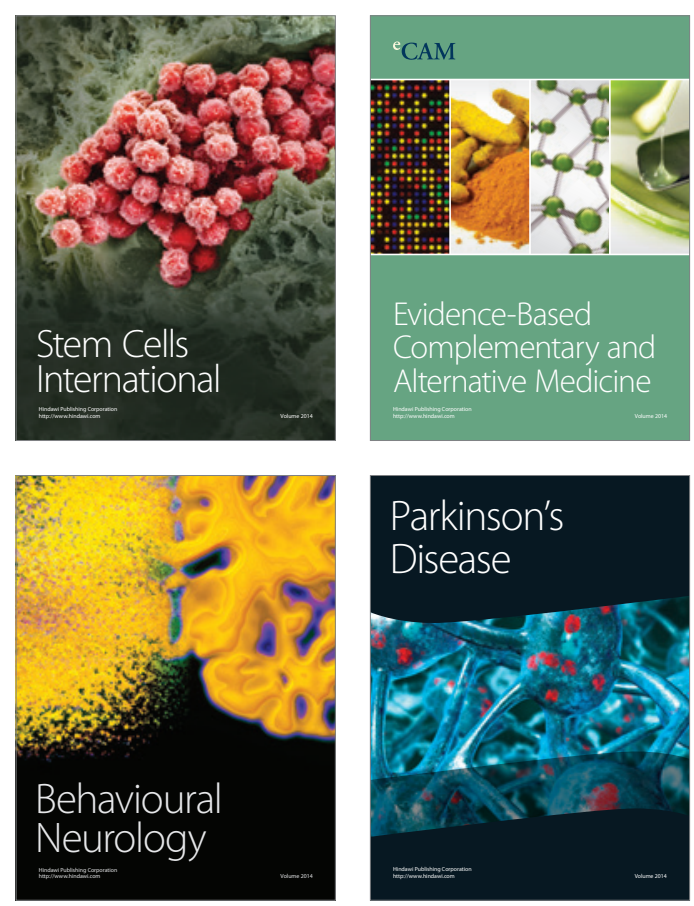

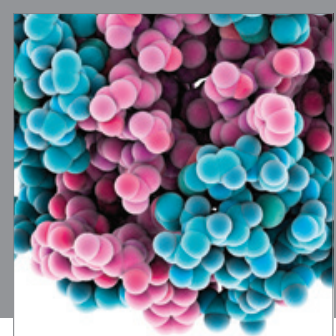

Journal of
Diabetes Research

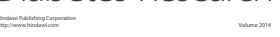

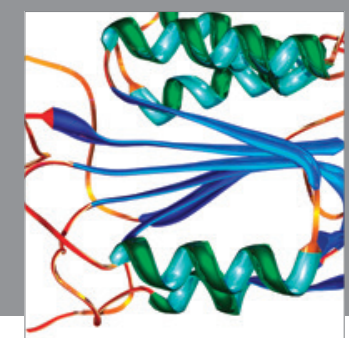

Disease Markers
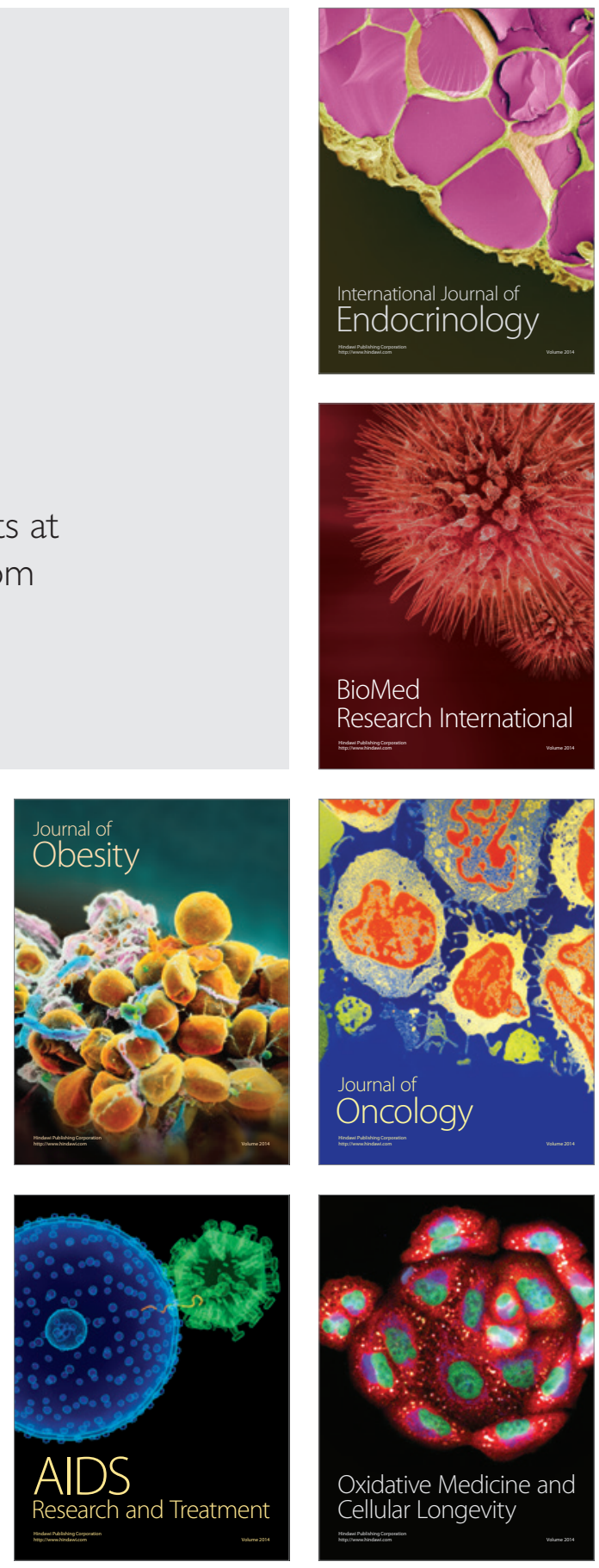